From Paris is Burning to \#dragrace: Social Media and the Celebrification of Drag Culture

Zeena Feldman $^{1}$ and Jamie Hakim ${ }^{2}$

${ }^{1}$ Department of Digital Humanities, King's College London, United Kingdom, UK ${ }^{2}$ Department of Film, Television and Media Studies, University of East Anglia, UK

King's College London, The Strand, Chesham Building 0.03, London, WC2R 5LS zeena.feldman@kcl.ac.uk

University of East Anglia, Norwich Research Park, 3.60 Arts, Norwich, NR4 7TJ j.hakim@uea.ac.uk 


\section{From Paris is Burning to \#dragrace: Social Media and the Celebrification of Drag Culture}

This article examines the celebrification of drag culture in the USA, and reflects on social media's role therein. This transformation is contextualised historically by charting the evolution of drag media representation from the subversive drag collectives immortalised in arthouse documentaries like The Cockettes (2002) to the emergence of highly-polished, brand-conscious celebrity drag entrepreneurs propelled to fame by the reality television programme RuPaul's Drag Race (2009-). The success of RuPaul's Drag Race (RPDR) has lent drag unprecedented levels of mainstream visibility. In so doing, we argue that RPDR has facilitated drag culture's move from the fringes to the mainstream, and contributed to drag's celebrification. In the second half of the article, we draw on celebrity studies and self-branding literatures to outline the central role that social media have played in the celebrification of drag culture. We also critique the politics this celebrification props up. Through analysis of queen-generated content on social media platforms, and of RPDR transcripts, we home in on the ethics of drag's celebrification - specifically the ways it supports homonormative narratives of the 'good queer' (Duggan 2003), and delimits the sorts of queer bodies and politics that are acceptable in the mainstream.

Keywords: RuPaul's Drag Race; social media; digital culture; capitalism, internet celebrity; reality television 


\section{Introduction}

Focusing on the American media ecosystem and the RuPaul's Drag Race franchise, this article argues that today's drag culture is 'celebrified': professionalised, commercially-viable, brand-oriented and mainstream. This 'celebrification', we demonstrate, is intimately connected to the rise of contemporary social media. To advance our argument, we bring the transformation of drag culture into dialogue with historic changes in media production, from the era of broadcast dominance to the current hegemony of user-generated online content. How has the shift from television and cinema to Instagram and YouTube affected the ways that drag queens understand and perform themselves? To what extent has the social media production context impacted drag's progressive identity and subversive politics? How does the emergence of multi-platform, celebrity drag queens connect with drag's history of critique?

Academic interest in the links between celebrity and politics is long-standing (e.g. Marshall 1997, Drake and Higgins 2006, Becker 2013, McKernan 2011). Some of this literature focuses on how established celebrities leverage their fame in support of political causes (Anderson 2008, Dejmanee 2013, Farrell 2012). But what happens to the relationship between celebrity and politics when the newly-minted star - in this case, the drag queen - is one who has traditionally been marginalised, stigmatised and an object of socio-economic exclusion? What becomes of the politics of subversion and opposition that are so intimately linked to an outsider subjectivity when that outsider is suddenly welcomed into the world of mainstream celebrity? 
We examine these questions through attention to the celebrification of drag and social media's role therein. One of our aims is to contextualise drag's transformation historically by charting the evolution of drag media representation from the subversive drag collectives immortalised in arthouse documentaries like The Cockettes (2002) and Paris is Burning (1990), to the emergence of the highly polished, brand-conscious celebrity drag entrepreneur propelled to fame by the reality television programme RuPaul's Drag Race (2009-). The success of RuPaul's Drag Race (RPDR) ${ }^{\mathrm{i}}$ has lent drag unprecedented levels of mainstream visibility (Oliver 2018). It has also launched a bevy of celebrity careers with multimedia derivatives, and in so doing, we argue that RPDR has facilitated drag culture's move from the fringes to the mainstream, and contributed to drag's celebrification.

The article's second aim is to draw on celebrity studies, social media and selfbranding literatures (e.g. Abidin 2018, Hearn 2014) in order to highlight the central role that social media platforms have played in the celebrification of drag culture. We also locate and critique the politics this celebrification props up (and disincentivises). Through analysis of queen-generated content across social media platforms, and of RPDR transcripts, we home in on the ethics of drag's celebrification - specifically the ways it supports homonormative narratives of the 'good queer' (Duggan 2003) and delimits the sorts of queer bodies and politics that are acceptable in the mainstream. Ultimately, analysis of the RPDR media empire and its social media footprint demonstrates that the celebrification of drag is today girdled by neoliberal imperatives and commercialised online platforms, wherein the transgressive drag collectivities captured in earlier media epochs have been displaced by the logic of individualism, competition and the market. 
This article proceeds in two parts. First, we show how social media and drag have, individually, evolved along a similar trajectory. Both began as landscapes of non-commercial niche amateurism. Over the last decade, however, both have transformed into spaces of and for commercial enterprise. With these parallel chronologies mapped out, the second portion of the article reflects on what this dual commercialisation means for how we think about drag in the social media age. Here, we show that drag - as an identity and a politics - is increasingly read through the lens of celebrity and as a branded commercial endeavour, where 'authenticity' is legitimate only insofar as a coherent persona is consistently performed (Fry, 2019). Our analysis suggests that social media's ubiquity in everyday life, and its centrality to the economics of drag celebrity, have further upped the ante.

One result of this is a dampening of drag's subversive potential - a constraining of its politics of critique. Less a project of subverting gender norms, or anti-capitalist politics, today's commercialised drag signals, results in and endorses 'a privatized, depoliticized gay culture anchored in... consumption' (Duggan 2003, p. 179), where drag has become a vehicle for enterprise as opposed to a means through which dominant power structures might be mocked, queried or dismantled.

\section{Internet, Professionalisation, Capital}

The initial domestication of the internet, and later the World Wide Web, in the 1980s and 1990s, produced vibrant spaces of self-expression and information sharing. From 
early bulletin board systems (BBS) and proto-social networking sites like The WELL (Rheingold 1993), Usenet (Hauben and Hauben 1997) and Internet Relay Chat (Burnett and Bonnici 2003) to the eclecticism of personal webpages and blogs (Milligan 2017, Lindemann 2005), the early Web was fertile ground for noncommercial socialisation and knowledge production. They were also spaces where stigmatised and disenfranchised subjects could connect with likeminded peers from all over the connected world (e.g. O'Riordan 2005). ${ }^{\text {ii }}$ This is not to suggest that the early Web was a utopia of inclusivity and acceptance. Indeed, it is important to note the rich scholarship that attends to online reproduction of offline racism, misogyny and homophobia (e.g. Silver 2000, Nakamura 2002). But equally, it is important to note that queer cultures did benefit from these newly networked spaces as they provided a means through which queer people, many of whom could not access the physical spaces of metropolitan gay neighbourhoods, were able to socialise (Campbell 2004). ${ }^{\text {iii }}$

Things began to change at the start of the $21^{\text {st }}$ century. There, sharp growth in internet penetration rates coincides with the emergence of brand names now associated with today's version of social media. LinkedIn and MySpace launch in 2003; Facebook and Flickr in 2004; Reddit and YouTube in 2005; Twitter in 2006 (boyd and Ellison, 2007). As the social media ecosystem began to take shape in the mid-2000s, we saw an accompanying lexicon emerge. Most notably, Tim O'Reilly (2005) furnishes the 'Web 2.0' buzzword. Originally a framework for understanding trends in software production, the term soon became shorthand for a participatory online media system of prosumers and their user-generated content (Bruns 2006, Ritzer and Jurgenson, 2010, Paltrinieri and Degli Esposti 2013). The language of Web 
2.0 gestured to the (alleged) defeat of traditional media gatekeepers and celebrates the (alleged) 'democratisation' of the means of production (Shirky 2008). Herein, the web was no longer the exclusive property of tech-savvy experts; it was now a terrain open - at least rhetorically - to everyone.

As platform access and content production became 'democratised', social media also became increasingly commercial and commercialised. In 2005, for instance, Rupert Murdoch’s News Corporation bought MySpace for \$580 million (Saga 2011). Less than a decade later, Facebook raised $\$ 16$ billion in its initial public offering and achieved a market capitalisation of \$104 billion (Rusli and Eavis 2012). Suddenly, there was a lot of money to be made from social platforms and their users.

Despite the veritable gold rush, social media continued to offer spaces to hobbyists, amateurs and the non-commercially minded (e.g. Fulton 2009, Fuchs and Sandoval, 2015). But as social media user counts grew, so too did the business of social media. Today's industry is complex and sophisticated, with myriad ad revenue models including affiliate programmes and brand ambassadorships (Miller 2013, Enders et al. 2008, Holton and Coddington 2012); digital agencies specialising in microtargeting and audience profiling (Barbu 2014); and a content marketing industry set to exceed $\$ 412$ billion by 2021 (Technavio 2017). This commercialisation has impacted social media use and users, affecting motivations for participating and specific practices and forms of content-generation (nb. Paasonen 2016). With social media now captured by the language, materiality and incentive structures of the market, online self-presentation has increasingly become a conduit for profit. It is in this context that we can understand the rise of micro-celebrities and social media 
influencers (Khamis et al. 2017, Raun 2018, Djafarova and Trofimenko 2019).

Likewise, this helps explain the emergence of the professional YouTuber - a figure starkly in contrast with that platform's early amateurism (Burgess 2012). Indeed, many scholars have previously shown that as platforms of self-expression become commodified, so too do the practices of self-production (e.g. Jarrett 2015, Iqani and Schroeder 2016, Thumim 2012, Banet-Weiser 2012, van Dijck 2013).

What started out as non-commercial spaces of and for niche audiences have, in the last decade, emerged as spaces of and for professional content producers and enterprising subjects (nb. Koffman et al. 2015). This transformation of social media's political economy helps anchor our analysis of RuPaul's Drag Race in the final portion of this article, allowing us to map social media's commercialisation onto the mainstreaming, professionalisation and celebrification of drag.

Before that, the following section charts the shift in drag culture from earlier amateur media and forms to the emergence of today's professionalised, platformed queens. This shift mimics what we describe above in regard to social media platforms. With drag, however, this transformation can be articulated as a move away from the drag balls shown in the iconic documentary Paris Is Burning (1990) to the celebrity queens who have emerged from RPDR. What does this shift tell us about the evolution of drag culture? How does it map onto web culture's own mainstreaming and commercialisation? And what does this reveal about contemporary social mores and norms more widely? 


\section{Drag of Yesteryear: From Anti-Capitalism to Ambivalence}

To be able to answer these questions, we first examine the relationship between drag and notions of professionalism that preceded RuPaul's Drag Race and its considerable social media footprint. Our analysis of pre-digital drag foregrounds more 'traditional' media forms: live performance and film. Within these, we find two general modes of drag represented. Firstly, drag which is intentionally un-professional and as such, functions as a means of anti-capitalist critique. Secondly, drag whose relationship to professionalism, and subsequently capitalism, is more ambivalent. We explore these in turn.

In the United States, there have been iterations of anti-capitalist drag since at least the 1960s. This mode of drag coincided with the period's feminist, gay and civil rights liberation movements and their critiques of gender, sexuality and race oppression. The drag troupe The Cockettes - arguably the most iconic exemplar of anti-capitalist drag - was forged in this progressive political moment. The Cockettes emerged as key players in San Francisco's hippie scene at the end of the 1960s (The

Cockettes 2002). Living in a commune amongst a network of similarly organised anticapitalist collectives, in the city's Haight Ashbury district, The Cockettes were the drag embodiment of Timothy Leary's (1966) invitation to 'Turn On, Tune In, Drop Out'. They put on free performances, shoplifted costumes and props, ate free food provided by neighbouring communes, and lived off state welfare (The Cockettes 2002). Ultimately, they defined themselves directly against and deliberately outside of America's capitalist norms. 
The Cockettes' performances playfully subverted gender expression and offered free-wheeling, bawdy yet utopian visions of how social, economic and gender relations might be organised differently. Shows like Tinsel Tarts in a Hot Coma (1971) and Journey to the Center of Uranus (1972) were deliberately amateurish in style in ways that worked to critique the formulaic predictability and professionalism of capitalist cultural production. Some of their work explicitly challenged capitalism, for instance their short film Elevator Girls in Bondage (1972) in which drag queen elevator girls gather beneath a portrait of Karl Marx and try to organise against their economic exploitation. The Cockettes were emblematic of the West Coast counterculture (Turner 2010) and the influence of their politics and transgressive style influenced a whole thread of subsequent drag culture, from the Radical Faeries (Lecker 2015) to Vaginal Crème Davis (Muñoz 1997) to the UK-based performance artist David Hoyle (Oliver 2014). As ideological descendants of The Cockettes, these artists use avant-garde drag aesthetics in ways that set out to undermine the gender norms and consumerist orientations of capitalist societies.

While anti-capitalist drag offers moments of important, culturally resonant critique, it was, and it remains, a fringe activity. With few exceptions (e.g. the Australian drag queen-cum-TV star Dame Edna Everage), Anglo-American drag culture has had an ambivalent relationship to professionalism and mainstream success. For decades, drag artists existed outside of the cultural conditions that might have enabled and supported the development of professional careers. Drag queens were outsiders, and within American capitalism, this 'otherness' extended beyond the cultural to the economic. As such, drag performers have long had a necessarily ambivalent relationship to capitalism. 
This ambivalence is best captured by the Harlem ball scene of the 1980s, as represented in the cult documentary Paris is Burning (1990) and later, in Ryan Murphy's television series Pose (2018-2019). This drag scene has its roots in the late $19^{\text {th }}$ century and is comprised of mostly African-American and Latinx queer people competing in balls. Here, competition involved convincingly dressing up - or in the language of the balls, 'passing' - as a particular type of person, often of the opposite gender. In its 1980s iteration this frequently meant 'passing' as a recognisable, prominent archetype of the time: a yuppie, a stockbroker, a runway model.

That Paris Is Burning takes place in Reagan's America (1981-1989) is not insignificant. Indeed, the above archetypes reflect the political economy of the historical moment in which they are performed. Reagan's America is a template of late capitalism and its contradictions: a systemic attack on the social safety net; conspicuous consumption; tax cuts; union-busting and deregulation; and a booming stock market (Anderson 1990, Wills 2017). Here, Madonna's (1984) song 'Material Girl' enjoys Billboard success (Caulfield 2017) at the same time that state welfare cuts reduce (some) people's access to the 'material world' the song fetishes (Stoesz and Karger 1993). While media culture celebrated consumption, government policy foreclosed on the material subsistence available to society's neediest - to those, like drag queens and people of colour, who were systemically excluded from capitalism's warm embrace. This historic assault on the welfare state thus posed a fundamental challenge to the very viability of the anti-consumerist drag performed and articulated by The Cockettes and their anti-capitalist compatriots. 
Paris Is Burning is also situated in Cold War America, with its rigid understandings of 'right' and 'wrong' (Stuckey 1995). 'Good' citizenship in this context is associated with virulent capitalism, heteronormativity and individualism. Conversely, the 'bad' subject is one who advocates for the collectivism, the welfare state and gender/sexuality fluidity. Thus, the Black and Latinx queens represented in Paris is Burning (and later, in Pose) are living on the fringes of society in multiple ways. They attend drag balls because these are among the few safe spaces to which they have access in an otherwise hostile America. And while the queens' ball ensembles often emulate the aesthetics of America's luxury consumer culture, the performances are essentially play-acting. In the Harlem balls, the aesthetics of wealth are recreated with stolen, found, handmade and second-hand goods precisely because drag does not yet offer a viable career, much less mainstream fame. Indeed, the protagonists of Paris is Burning discuss their 'mopping' (i.e. stealing) practice as the only way they can access the culture's fixation with brand names and consumerism. They also refer to the fact that they sometimes do not eat for days so that they can save enough money for their ball looks. The balls, then, function as spaces for selfexpression, self-actualisation and communality set against a backdrop of economic marginalisation. Thus, when ball emcees and attendees express their approval of a queen's look by proclaiming 'You own everything', the phrase does complex conceptual work: it signals a convincing embodiment of luxury while also gesturing to its temporariness and artifice. Where the simulacrum of abundance successfully 'passes' for the 'real thing', it remains inextricably linked to the fantasy of economic power and drag queens' historic exclusion therefrom. This analysis provides an interesting lens through which to understand the RPDR contestant Mercedes' repeated inability to pronounce the word 'opulence' (S11E2). 
The drag balls offered a temporary escape from the era's heteronormative capitalism. But they also reflect a profoundly ambivalent relationship with capitalism: the performances mimic its norms and articulate its aspirations while simultaneously providing a brief respite from systemic marginalisation. Desire sits alongside rejection, and critique alongside incorporation/interpellation.

The economic reality of other drag performers, as detailed in Esther Newton's landmark ethnography Mother Camp (1972), adds flesh to these bones. It is here that we begin to see a cleavage in the drag community, between performers interested in challenging capitalist hetero-patriarchy and those interested in a paying job. Where 'stage queens' did try to make a living, the working conditions were difficult. Newton explains that drag queens 'work long hours for little pay' (p. 4), noting

The highest weekly salary I ever heard of for a single female impersonator in a gay bar was $\$ 200$ a week, and this is exceptional. The average is closer to $\$ 75$ a week, with some salaries as low as $\$ 40$ (p. 116).

The weekly average Newton cites equates to an annual income of $\$ 3,900$, if the performer works 52 weeks a year. To put this in perspective, in the US, the average annual salary in 1979 was $\$ 11,479.46$ (Social Security Administration) approximately $295 \%$ of a stage queen's yearly income.

Alongside low earnings, Newton also points to the high costs of doing drag work. Much of this work occurs in gay bars, where customers are often regulars and thus 
expect to see new looks from repeat performers. The bar tab also adds up. With high costs and low wages, self-promotion becomes increasingly necessary for the enterprising queen and so we see the emergence of publicity flyers - another cost of doing business.

Ultimately, this mode of working relied on individual perseverance. There were no contracts, no unions, no other structures of formal organisation. Queens were often out of work or 'between jobs'. Where paying gigs did exist, they typically required performers to move from city to city, shuffling between collective living arrangements with others queens. Further complicating these conditions of production was a legal-political context in which police had impunity to harass and close down gay bars, thus making a precarious living all the more so. 'Like the majority of Americans [...] [drag queens] have no control at all over the conditions of their work; no job security, no collective strength' (Newton 1979, p. xx).

Then in the early-to-mid 1990s, we see the rare drag success story: RuPaul. In 1993, two singles from her Supermodel of the World album reach number 1 on Billboard's Hot Dance Music/Club Play chart. The self-pronounced 'Supermodel' then signs a modelling contract with MAC Cosmetics and in 1994, becomes the face of their Viva Glam campaign. After publishing the 1995 autobiography, Lettin' It All Hang Out, RuPaul co-hosts a morning radio programme in New York and from 1996 to 1998 , co-hosts a late-night talk show on the national cable television network VH1 (RuPaul 1998). 
This has all the trappings of the American dream: the individual from humble beginnings who worked hard and made a success of him/herself. It is a classic rags-toriches Horatio Alger story, with a drag queen as its central character. ${ }^{\text {iv }}$ While RuPaul's rise foreshadowed elements of today's drag moment, this success narrative also coincided with the rise of the World Wide Web: a communication medium that allowed (certain) marginalised audiences unprecedented access to voice and selfrepresentation. Between the fledgling world of professional 'female impersonators' that Newton documents and the early career achievements of RuPaul, we begin to see potent parallels with contemporary drag norms, as exhibited in RPDR. We turn our attention to these parallels below.

\section{Enter RuPaul's Drag Race: Drag and Social Media Convergence}

RuPaul's Drag Race first aired in 2009, on Logo TV - an American LGBT-focused cable television channel ( $\mathrm{Ng} 2013)$. Following the enormous commercial success of talent shows like Big Brother and Pop Idol, RPDR funnelled some aspects of the drag cultures described above into the traditional competition reality show format. In weekly episodes, drag queens compete in a task and a runway challenge. The two 'worst performers' of each episode then compete against each other in a lipsync performance, with the loser sent home. The weekly eliminations culminated in the last queen standing being crowned 'American's Next Drag Superstar' and in the first season, winning a cash prize of $\$ 20,000, \$ 5,000$ worth of MAC cosmetics, a spot in an LA Eyeworks advertising campaign and a job touring with the Logo Drag Race tour. ${ }^{\mathrm{v}}$ 
As with many reality television programmes, social media has played an instrumental part in the show's success, as well as in the business model the show's production company, World of Wonder, built around it. RuPaul routinely directs viewers to 'participate' in Drag Race through a hashtag: \#dragrace. In later seasons, audiences are also encouraged to express their support for their favourite finalist via hashtag. Here, social media platforms are positioned as proxies for community but they also work to enlarge RDPR's cultural-cum-economic footprint. Social media participation produces metrics, which act as evidence of user 'engagement' while also facilitating the monetisation of that engagement (nb. Beer 2016). Where fans livetweet episodes or post \#TeamMonetXchange content on Instagram, for example, they are extending the franchise's cultural and economic reach. (They are also adding to Twitter and Instagram's data inventories.) Indeed, Drag Race's social media footprint is massive. As of 8 October 2019, the show had 2.8M Instagram followers; $2.29 \mathrm{M}$ Facebook followers; 969K Twitter followers; and 1.35M subscribers to World of Wonder's YouTube channel. Yet these figures reflect only official RPDR social channels - a sliver of the show's broader social media presence, populated by extensive fan-generated content and the individual accounts of featured queens and judges. Indeed, many of the show's alumni have amassed considerable social media followings (detailed below).

According to the media industries scholarship on reality television, the success of the current format depends almost entirely upon its enmeshment with the professionalised social media infrastructures we outline above (e.g. Deery 2014). In this sense RuPaul's Drag Race is a representative case of a broader logic. What this 
means for the production of celebrity within reality television is cogently addressed by the work of Alison Hearn $(2008,2014,2017)$. Hearn argues that reality television contains too many types of television to be understood as a single genre in its own right and instead is best conceived of as 'a series of cost-cutting measures in mainstream television production enacted by management as a response to the economic pressures faced by the television industry transnationally in the late 1980s and 1990s' (2014, p. 439) One of the major costs cut was personnel: instead of unionised writers and actors, reality television shows employed low-cost producers and no-cost 'real people'(Williamson 2016).

The rationale offered to these 'real people' for providing free labour is that the television programme gives them a 'free' platform on which to launch their celebrity personae. Subsequently, social media affordances could be harnessed to grow their nascent brands. As Hearn (2014) suggests, this method of 'self-branding' is located at the intersection of reality television and social media communication. With selfbranding now characteristic of the contemporary production of celebrity, social media platforms become increasingly central to these practices. Indeed, it is within this context that we can make sense of what Crystal Abidin (2018) dubs 'internet celebrity' - a form of entrepreneurial self-branding enabled by social media's ability to facilitate direct communication between a star and their fans. Social media platforms are thus essential to making possible both contemporary celebrity and contemporary fandom.

RuPaul's Drag Race, as a reality television show with a considerable social media presence, is informed by the industrial logic Hearn outlines. It is unsurprising 
then that the show's most 'successful' participants become celebrities within the terms of this logic: the show provides them with a platform to launch themselves as media personalities, and then social media savvy enables them to further market themselves, to grow their fanbase and ultimately, to become drag entrepreneurs. The remainder of this article will provide evidence from the show itself as well its social media content to demonstrate how RPDR drag queens explicitly construct themselves as professional, entrepreneurial self-brands. It will then consider the figure of drag queen as self-brand within the longer history of drag outlined earlier, so as to understand the ethical implications of the pre-eminence of this sort of drag celebrity within the current historical conjuncture.

\section{The Queens of Drag Race: Competitive, Hard-'Werqing’ Self-Brands}

For the contestants of RuPaul's Drag Race, a social media presence is all but compulsory. Instagram is currently the dominant platform for drag queens, arguably because its emphasis on imagery supports drag's long-standing connection to visual culture and is particularly well-suited to showcasing a queen's distinctive looks. Twenty-two former Drag Race contestants have now surpassed 1 million Instagram followers (RuPaul's Drag Race Wiki). Such social media popularity often gestures to the accountholder's offline success, and indeed, of the twenty-two queens in the 'million follower club', many have developed prolific multimedia careers that include touring but also extend to YouTube, film, television and music production (Turchiano 2018). 
Drag Race queens frequently frame their social media participation through the discourse of celebrity and entrepreneurial self-branding. For instance, Jasmine Masters (S7 and All Stars S3) has said:

Yeah, cause once you're on [social media], you are a reality celebrity. You are a brand from that point, you know, so you have to treat yourself as a market, as a business.... So you have to think, company-wise, you have to think of yourself as a brand because you are a brand now (in Schotmiller 2017, p. 283).

Masters has in fact mastered the use of social media to self-brand. Despite performing poorly on both of her RPDR seasons she has achieved the status of fan favourite largely through the virality of memes that are produced from videos she uploads onto her YouTube channel.

Indeed, an active social media presence is increasingly regarded as essential to the making of a contemporary drag career. West Hollywood based drag queen Cake Moss aspires to be a RPDR contestant and is keenly aware of the importance of social media to achieving RPDR levels of success.

You have to like at least post one or two photos a day on social media and post in general just to keep your place. It's weird, it's interesting. Cause I've noticed that of the older queens that aren't really savvy with technology and social media and all that, they're just being swept under the rug (in Schotmiller 2017, p. 268). 
Social media engagement is presented here as both necessary and central to today's drag profession. Yet Drag Race contestants who are seen as too closely affiliated with social media are routinely dismissed by competing queens. Silky Nutmeg Ganache, for example, rejects the idea that her Season 11 colleague Ariel poses meaningful competition precisely because

Ariel is a social media girl. So I think it's a difference for her being in a situation where she's with real entertainers. She's one note. She don't really have a personality. She's an Instagram ho. Nobody care, nobody care (S11E3, emphasis original).

For Ariel, being seen as a primarily social media queen raise scepticism about her charisma, uniqueness, nerve and talent. Yet we also see, through Jasmine Masters and Cake Moss, that social media is nonetheless regarded as necessary to the viability of a successful drag career.

Indeed, social media self-branding is understood by many Drag Race contestants as central to their post-show careers. The topic has even formed the basis of discussion panels held at the thrice annual RuPaul's Drag Race fan convention 'RuPaul's Drag Con'. One such panel called 'Brand Me!' (2016) featured Drag Race contestant Laganja Estranja reflecting on how her appearance on the show and audience's social media responses to this informed her post-show entrepreneurial selfbranding strategy and social media usage. Laganja explained that the show launched her as a 'character' that was built around her 'catchphrases', her 'meltdowns' and her drag style's incorporation of cannabis references. On Twitter, Instagram and 
elsewhere, this character was one that many of the show's fans loved to hate, so on the panel Laganja explained how she set about 'rebranding herself' by leveraging this negative audience reaction: 'Oh girl, you think I'm too much, now I'm \#teamtoomuch, and now you can see me on tour'. She claimed that social media hashtags are key to her self-branding, not only hashtagging her catchphrases, which have become iconic to the Drag Race audience, but also giving nomenclature to her fanbase: \#buds (referring to the buds of a cannabis plant). ${ }^{\mathrm{vi}}$ Most social media commentators agreed that Laganja gave a middling performance on RPDR, including her turn on the show's talent contest 'Snatch Game'. As such, a carefully cultivated, social media-based self-branding strategy has been crucial to the professional construction of her celebrity and post-show career. For both Laganja and Jasmine Masters, their celebrity stems more from their social media self-branding than from the more traditional ingredients of a drag persona: the drag look and performance style.

The purpose of branding is to make a product - in this case, one's self distinctive within a competitive marketplace. In today's drag, much of that branding takes place within increasingly accessible but also increasingly crowded social media feeds. One result of this has been intensification of the competitiveness that Newton (1972) found to be an everyday feature of a drag queen's working life. This competitiveness is, of course, compounded by the fact that RPDR is itself a competition. Yet we can also chart how, over time, the explicit values and stakes of competition impacted the show's content and affective texture. The early seasons of RPDR feature queens who are rough around the edges - for instance, in their makeup application, hair and wig skills, fashion acumen and padding. But as the show 
progresses, we see fewer unpolished queens. The increased gloss brings with it a change in the discussion topics among contestants and also their narratives of selfpresentation. Earlier seasons routinely feature heart-warming stories of individual struggle and perseverance-against-all-odds. Later seasons foreground queens discussing their social media followers, their brands, their careers. The (sympathetic) figure of the social outcast is slowly replaced by the professional and hungry entrepreneur - exemplified in All Stars 3 when contestant Morgan McMichaels notoriously announced 'I'm here to win; [I] will get rid of my competition'. As discussed above, this displacement of the amateur by the professional/enterprising subject coincides with and maps onto a similar move in social media production.

A definitive aspect of the drag entrepreneur as self-brand that characterises successful contestants of RuPaul's Drag Race is the embrace of the imperative to 'work', or in the parlance of the show, 'werq'. This extraordinary emphasis on working is where the culture of drag that the show privileges departs most clearly from the radical forms of drag discussed at the beginning of this article and that we have exemplified using The Cockettes. The term 'werq' is used across drag as well as LGBTQ+ cultures in the US (and elsewhere) as an affirmation of something that someone has said or done. The term is constantly used in the show as well as in its various spin-offs and associated content. The significance and ontological centrality of the term is perhaps most vividly illuminated in fan favourite Shangela's song Werqin' Girl (2012). In contrast to RuPaul's Supermodel (You Better Work), which is largely about the fantasy of the glamorous life of a supermodel (regular fayre in US drag queen and ball culture, which often aspires to the aesthetics of hyper-femininity), Werqin' Girl is a braggodocio track in which Shangela boasts about her status as a 
paid professional. The lyrics begin with the line 'Move aside amateurs!' and continue into the chorus:

I'm a pro

Pro

I'm a pro

Uh I am a professional

Pro

I'm a pro

I'm a pro

Uh I'm a professional

Work (work work)

I came to work (work work)

I'm here to work (work work)

I told y'all I was a professional

The song fetishes hard work and tenacity. In reference to her tireless work ethic, Shangela explains that her work is:

No 9 to 5

Around the clock

Overtime

Haters cannot touch my drive 
The discursive insistence on professionalism and hard work is reinforced affectively through the song's intense and abrasive sound as well as the music video's choreography, which can best be described as frenetic. Indeed, Shangela's construction of herself as a hard-working queen has paid off and her celebrity profile now extends well beyond the Drag Race universe. In addition to several music singles, she has many film and TV credits to her name, including on Glee (2012); Broad City (2019); and the Lady Gaga vehicle A Star is Born (2018). In the celebrity persona that is Shangela, exemplified by her single Werqin' Girl and its explicit celebration of the hard working, professional, self-branded drag entrepreneur, we are a world away from the free-wheeling, anti-establishment, anti-capitalist drag that preceded RuPaul's Drag Race. That earlier drag - less professional but more political - has been all but eclipsed by the genre's mainstream success. Indeed, in a Drag Con panel titled 'The Business of Drag' (2016), Latrice Royale makes clear that today, 'Drag is not hobby, it's a career'.

\section{Conclusion}

RuPaul's Drag Race represents the high watermark of mainstream success for drag culture in the US (and elsewhere). This success has been enabled in large part by the ways that World of Wonder has funnelled key aspects of US drag culture into the reality TV format. As previously stated, this format is dependent on a complex, commercialised social media infrastructure designed to increase audience engagement and maximise revenue in an ever-more-competitive media ecology. The effect that 
this has had on the celebrification of the show's drag queens and therefore the type of drag that achieves visibility in the mainstream is significant.

Whereas prior to the show's success, US drag cultures existed either in opposition to, or were side-lined by, American capitalism, the drag culture that most people consume now, both inside and outside LGBTQ+ communities, is thoroughly imbued with the logic and mechanics of capitalism. RPDR drag queens routinely frame their drag and their social media engagement as forms of professional selfbranding. In the process, relations between the drag queens have become more competitive and drag's articulated values far more work-oriented than in previous iterations of the art form. That this transformation has paralleled similar shifts in social media practice and organisation is not coincidental; it is, we are arguing, precisely because of the opportunities proffered by the highly capitalist arrangement of contemporary social media that this neoliberal, professional version of drag has become hegemonic.

What does all this mean for US drag? As fans of the show and of drag culture more generally, we find much to celebrate about the proliferation of social media drag content and its increased visibility in the mainstream. But we are also left wondering what has been gained and lost by this version of drag in particular becoming hegemonic over the forms outlined in the first half of this article. Of course, all performers - drag or otherwise - should receive fair recompense for their labour and should be able to carry out their work in full-time capacities should they so desire. A professionalised and capitalist form of social media has, to some degree, enabled this for a handful of US drag queens, in ways that were simply not possible before its 
emergence. ${ }^{\text {vii }}$ As LaTrice Royale (2016) marvelled at 'The Business of Drag' Drag Con panel: 'When has it ever been possible for drag to be a viable career? Who knew?'.

Of course, there remain other ways of doing drag, and other reasons for doing it. As mentioned above UK based drag artist David Hoyle remains active and deliberately uses drag performance to articulate anti-capitalist and other progressive political positions. But the polished, professional, multi-platform queen celebrated on RPDR is the hegemonic model today. Likewise, there are many ways of using social media (and many reasons for doing so). But the professionalised, entrepreneurial content creator is the subject position that currently has the greatest visibility, legitimacy and cultural purchase. This parallel professionalisation of drag and social media tells us something about the contemporary world and its values. What's valorised is entrepreneurial individualism and competitiveness, beauty/polish, hard work and a clearly articulated identity: the brand needs to be immediately apparent and consistently performed (nb. Hearn).

All of this takes a lot of work. It arguably requires a lot more work than the early Cockettes shows, where the commune just showed up at the theatre, got on stage, and let whatever happened happen. The spontaneity and artistic anarchism of The Cockettes has been replaced by the extensive planning and staging required by the contemporary content industries.

Yet we contend that as an art form, drag is at its most powerful when it questions dominant arrangements of power and dominant frameworks of social 
reproduction. As Paris is Burning shows, it is possible to critique power whilst simultaneously seeking access to it. Or in the case of The Cockettes, we see drag used as a means of more forcefully disrupting existing power structures. While RuPaul's Drag Race puts forward a far less confrontational and transgressive style of drag, its capacity to challenge the status quo remains. Our culture has yet to reach a stage where 'a man dressed as a woman' is a normative act. However, in achieving celebrity and mainstream success through professionalised, commercialised forms of social media, drag queens are increasingly becoming willing agents of the hegemonic power that was previously denied them.

\section{References}

Abidin, C., 2018. Internet celebrity: understanding fame online. United Kingdom: Emerald Publishing.

Anderson, E., 2008. Treacherous Pin-ups, Politicized Prostitutes, and Activist Betrayals: Jane Fonda's Body in Hollywood and Hanoi. Quarterly Review of Film and Video, 25 (4), 315-333.

Anderson, M., 1990. The Reagan Boom - Greatest Ever. The New York Times, 17 January, p. 25. 
Banet-Weiser, S., 2012. Authentic ${ }^{T M}$ : The Politics of Ambivalence in a Brand Culture. New York and London: New York University Press.

Barbu, O., 2014. Advertising, Microtargeting and Social Media. Procedia: Social and Behavioral Sciences, 163, 44-49.

Becker, A.B., 2013. Star Power? Advocacy, Receptivity, and Viewpoints on Celebrity Involvement in Issue Politics. Atlantic Journal of Communication, 21 (1), 1-16.

Beer, D., 2016. Metric Power. London: Palgrave Macmillan.

boyd, d.m. and Ellison, N.B., 2007. Social Network Sites: Definition, History, and Scholarship. Journal of Computer-Mediated Communication, 13 (1), 210-230.

"Brand Me!" featuring Manila Luzon, Laganja Estranja, AB Soto and Jackie Huba at DragCon 2016., 2016. Available at:

https://www.youtube.com/watch?v=sXxeG5aWToQ [Accessed 14 October 2019].

Bruns, A., 2006. Towards Produsage: Futures for User-Led Content Production. In: F. Sudweeks, H. Hrachovec and C. Ess, eds. Proceedings of Cultural Attitudes Towards Communication and Technology 2006, 28 June - 1 July 2006, Tartu, Estonia, 275284. 
Burgess, J.E., 2012. YouTube and the formalisation of amateur media. In: D. Hunter et al., eds. Amateur Media: Social, Cultural and Legal Perspectives. Oxon: Routledge, 53-58.

Burnett, G. and Bonnici, L., 2003. Beyond the FAQ: Explicit and implicit norms in Usenet newsgroups. Library \& Information Science Research, 25 (3), 333-351.

Caulfield, K., 2017. Madonna's 40 Biggest Billboard Hits [online]. Available from: https://www.billboard.com/articles/list/499398/madonnas-40-biggest-billboard-hits [Accessed 13 September 2019].

Campbell, J. E., 2004. Getting It On Online: Cyberspace, Gay Male Sexuality, and Embodied Identity. London: Routledge.

Deery, J., 2014. Mapping Commercialisation in Reality Television. In: L. Oullette, ed. A Companion to Reality Television. Chichester: John Wiley \& Sons, 11-28.

Dejmanee, T., 2013. The burdens of caring. Australian Feminist Studies, 28 (77), $311-322$.

Djafarova, E. and Trofimenko, O., 2019. 'Instafamous': Credibility and selfpresentation of micro-celebrities on social media. Information, Communication \& Society, 22 (10), 1432-1446. 
Drake, P. and Higgins, M., 2006. 'I'm a celebrity, get me into politics': The political celebrity and the celebrity politician. In: Su Holmes and Sean Redmond, eds. Framing Celebrity: New Directions in Celebrity Culture. London and New York: Routledge, 87-100.

Duggan, L., 2003. The twilight of equality? Neoliberalism, cultural politics and the attack on democracy. Boston: Beacon Press.

Enders, A. et al., 2008. The long tail of social networking: Revenue models of social networking sites. European Management Journal, 26 (3), 199-211.

Farrell, N., 2012. Celebrity Politics: Bono, Product (RED) and the Legitimising of Philanthrocapitalism. The British Journal of Politics and International Relations, 14 (3), 392-406.

Fry, N., 2019. Just be yourself. The New Yorker, 1 Apr, pp. 28-31.

Fuchs, C. and Sandoval, M., 2015. The political economy of capitalist and alternative social media. In: C. Atton, ed. The Routledge Companion to Alternative and Community Media. Oxon and New York: Routledge, 165-176.

Fulton, C., 2009. Quid Pro Quo: Information Sharing in Leisure Activities. Library Trends, 57 (4), 753-768. 
Hauben, M. and Hauben, R., 1997. Netizens: On The History and Impact of Usenet and the Internet. Los Alamitos, CA: IEEE Computer Society Press.

Hearn, A., 2008. Insecure: Narratives And Economies Of The Branded Self In Transformation Television. Continuum: Journal of Media \& Cultural Studies, 22 (4), 495-504.

Hearn, A., 2014. Producing "Reality" Branded Content, Branded Selves, Precarious Futures. In: L. Oullette, ed. A Companion to Reality Television. Chichester: John Wiley \& Sons, 437-456.

Hearn, A. (2017) Verified: Self-Presentation, Identity Management, and Selfhood in The Age of Big Data. Popular Communication, 15 (2), 62-77.

Holton, A. and Coddington, M., 2012. Recasting social media users as brand ambassadors: Opening the doors to the first 'Social Suite.' Case Studies in Strategic Communication, 1, 4-24.

Iqani, M. and Schroeder, J.E., 2016. \#selfie: digital self-portraits as commodity form and consumption practice. Consumption Markets \& Culture, 19 (5), 405-415.

Jarrett, K., 2015. Feminism, Labour and Digital Media: The Digital Housewife. New York: Routledge. 
Khamis, S., Ang, L. and Welling, R., 2017. Self-branding, 'micro-celebrity' and the rise of Social Media Influencers. Celebrity Studies, 8 (2), 191-208.

Lecker, M., 2015. Welcome Home: Radical Faeries and Queer Worldmaking. Thesis $(\mathrm{PhD})$. George Mason University.

Leary, T., 1966. Turn On, Tune In, Drop Out. Oakland, CA: Ronin Publishing.

Lindemann, K., 2005. Live(s) Online: Narrative Performance, Presence, and Community in LiveJournal.com. Text and Performance Quarterly, 25 (4), 354-372.

Marshall, P.D., 1997. Celebrity and power: fame in contemporary culture. Minneapolis and London: University of Minnesota Press.

McKernan, B., 2011. Politics and Celebrity: A Sociological Understanding. Sociology Compass, 5 (3), 190-202.

Miller, P., 2013. Social Media Marketing. In: A.B. Albarran, ed. The Social Media Industries. New York and London: Routledge, 86-104.

Milligan, I., 2017. Welcome to the web: The online community of GeoCities during the early years of the World Wide Web. In: N. Brügger and R. Schroeder, eds. The Web as History. London: UCL Press, 137-158. 
Muñoz, J. E., 1997. "The White to Be Angry": Vaginal Davis's Terrorist Drag. Social Text, 52/53, 80-103.

Nakamura, K., 2002. Cybertypes: Race, Ethnicity, and Identity on the Internet. New York and London: Routledge.

Newton, E., 1972. Mother camp: female impersonators in America. Chicago: University of Chicago Press.

Ng, E., 2013. A ‘Post-Gay’ Era? Media Gaystreaming, Homonormativity, and the Politics of LGBT Integration. Communication, Culture \& Critique, 6 (2), 258-283.

Oliver, D., 2014. You're funnier when you're angry. Performance Research, 19 (2), $109-115$.

Oliver, I., 2018. Is this the golden age of drag? Yes and no. The New York Times [online] Available from: https://www.nytimes.com/2018/01/17/arts/drag-queensrupaul-drag-race.html [Accessed 3 May 2019].

O'Reilly, T., 2005. What is Web 2.0: Design patterns and business models for the next generation of software [online]. Available from: https://www.oreilly.com/pub/a/web2/archive/what-is-web-20.html [Accessed 21 September 2019]. 
O’Riordan, K., 2005. From Usenet to Gaydar: A Comment On Queer Online Community. ACM SigGroup Bulletin, 25 (2), 28-32.

Paasonen, S., 2016. Fickle focus: Distraction, affect and the production of value in social media [online], First Monday, 21 (10). Available from:

https://doi.org/10.5210/fm.v21i10.6949 [Accessed 21 September 2019].

Paltrinieri, R. and Degli Esposti, P., 2013. Processes of Inclusion and Exclusion in the Sphere of Prosumerism. Future Internet 5, 21-33.

Raun, T., 2018. Capitalizing intimacy: New subcultural forms of micro-celebrity strategies and affective labour on YouTube. Convergence: The International Journal of Research into New Media Technologies, 24 (1), 99-113.

Rheingold, H., 1993 [2000]. The Virtual Community: Homesteading on the Electronic Frontier. Cambridge: Addison Wesley and MIT Press.

Ritzer, G. and Jurgenson, N., 2010. Production, Consumption, Prosumption: The nature of capitalism in the age of the digital 'prosumer'. Journal of Consumer Culture $10(1), 13-36$.

Rusli, E. and Eavis May, P., 2012. Facebook raises $\$ 16$ billion in I.P.O. The New York Times [online]. Available from:

https://dealbook.nytimes.com/2012/05/17/facebook-raises-16-billion-in-i-p-o/?hp [Accessed 14 October 2019]. 
RuPaul, 1998. Lettin in All Hang Out: An Autobiography. London: Warner Books.

RuPaul's Drag Race Wiki, Queens With 1 Millions Followers of More on Instagram [online]. Available from:

https://rupaulsdragrace.fandom.com/wiki/Category:Queens_with_1_Million_Followe rs_or_More_on_Instagram. [Accessed 5 June 2019].

Saga, J., 2011. News Corp sells Myspace, ending six-year saga [online]. Available from: http://uk.reuters.com/article/2011/06/29/us-newscorp-myspaceidUSTRE75S6D720110629 [Accessed 22 June 2019].

Schotmiller, C., 2017. Reading RuPaul's Drag Race: Queer Memory, Camp Capitalism, and RuPaul's Drag Empire. Thesis (PhD). UCLA.

Shirky, C., 2008. Here Comes Everybody: The Power of Organizing Without Organizations. New York: Penguin Press.

Silver, D., 2000. Margins in the wires: Looking for race, gender, and sexuality in the Blackburg Electronic Village. In: B.E. Kolko, L. Nakamura and G.B. Rodman, eds. Race in Cyberspace. New York and London: Routledge, 133-150.

Social Security Administration. National Average Wage Index [online]. Available from: https://www.ssa.gov/oact/COLA/AWI.html [Accessed 14 October 2019]. 
Stoesz, D. and Karger, H.J., 1993. Deconstructing Welfare: The Reagan Legacy and the Welfare State. Social Work, 38 (5), 619-628.

Stuckey, M.E., 1995. Competing foreign policy visions: Rhetorical hybrids after the Cold War. Western Journal of Communication, 59 (3), 214-227.

Technavio, 2017. Global Content Marketing Market 2017-2021 Report [online] Available from https://www.technavio.com/report/global-content-marketing-market [Accessed 14 October 2019].

The Cockettes, 2003 [2002]. DVD. London: Tartan DVD.

"The Business of Drag" Feat. Latrice Royale and Mimi Imfurst at RuPaul's DragCon2016!, 2016. Available from:

https://www.youtube.com/watch?v=MFS45z jvTw. [Accessed: 14 October 2019].

Thumim, N., 2012. Self-Representation and Digital Culture. Basingstoke and New York: Palgrave Macmillan.

Turchiano, D., 2018. 'RuPaul's Drag Race' at 10: launching the next wave of drag superstars. Variety [online]. Available from: https://variety.com/2018/tv/news/rupauldrag-race-most-successful-queens-1202715507. [Accessed 14 October 2019]. 
Turner, F., 2006. From counterculture to cyberculture: Stewart brand, the whole earth network, and the rise of digital utopianism. Chicago: University of Chicago Press.

van Dijck, J., 2013. The Culture of Connectivity: A Critical History of Social Media. Oxford and New York: Oxford University Press.

Williamson, M., 2016. Celebrity: capitalism and the making of fame, Cambridge: Polity.

Wills, G., 2017. Reagan's America: Innocents at Home. New York: Open Road Media.

Wood, A.J. et al., 2019. Networked but Commodified: The (Dis)Embeddedness of Digital Labour in the Gig Economy. Sociology, 53 (5), 931-950.

\footnotetext{
${ }^{\text {i }}$ At the time of writing, the show has aired 11 'regular' seasons and 4 All Star seasons in the US. In October 2019, RPDR broadcast its first UK season on BBC 3.

ii It is important to qualify the early web's ability to support connectivity and conviviality, given its relative exclusivity. Participation was limited to those with sufficient financial and technical capital. In December 1995, for instance, there were only 16 million internet users worldwide - less than half of one percent of the world's population. See Internet World Stats, 2019. Internet growth statistics. Available from: https://www.internetworldstats.com/emarketing.htm [Accessed 14 October 2019]. ${ }^{\text {iii }}$ More recent scholarship on trans* digital culture argues that digital infrastructures serve a similar role for trans* folk. See Cavalcante, A., 2016. 'I Did It All Online:' Transgender Identity and The Management of Everyday Life. Critical Studies in Media Communication, 33 (1), 109-122.

iv Indeed, the hit single Supermodel (You Better Work) (1993) that launched RuPaul's mainstream career begins with the lyrics 'Once upon a time, there was a little black girl/In the Brewster Projects of
} 
Detroit, Michigan/At fifteen, she was spotted by an Ebony Fashion Fair talent scout/And her modelling career took off/You better work'.

${ }^{\mathrm{v}}$ Interestingly, the $\$ 20,000$ pay day represented less than $50 \%$ of the average annual wage in America in 2009 (National Wage Index). In succeeding seasons, the cash prize increases: to $\$ 25,000$ in season 2 (2010); \$75,000 in season 3 (2011); and since season 4 (2012), has held steady at $\$ 100,000$. It is only in season 3 that the cash prize exceeds the average annual wage in the US (ibid.).

${ }^{\text {vi }}$ The naming and hashtagging of fanbases is a common branding tactic of mainstream celebrities. For instance, Mariah Carey has her \#Lambily, Beyonce her \#BeyHive and Nicki Minaj her \#Barbies.

${ }^{\text {vii }}$ At its apex, commercialised social media takes the form of gig economy apps (see e.g. Wood et al. 2019). Functionally, such platforms take the promotional affordances of social media to their natural conclusion, by facilitating direct commercial transactions between service buyers and sellers. 